Jurnal Mengenai Dasar-Dasar Pemikiran Hukum: Filsafat dan IImu Hukum Tersedia online di https://ejournal2.undip.ac.id/index.php/crepido/

Volume 01, Nomor 01, Juli 2019

\title{
URGENSI PENALARAN DALAM ARGUMENTASI HUKUM GUNA MENGEMBANGKAN PEMIKIRAN HUKUM YANG KOMPREHENSIF
}

\author{
Tri Rahayu Utami ${ }^{*}$, Aditya Yuli Sulistyawan \\ Fakultas Hukum Universitas Diponegoro \\ Jl. Prof. Soedarto, S.H., Tembalang, Semarang \\ tria2809@gmail.com
}

\begin{abstract}
Reasoning has a very important role in the development of knowledge and assessments of certain knowledge. As a science it becomes the basis that determines thinking to be straight, precise and healthy. Because the function of reasoning is to investigate, formulate and apply the laws that are kept. Reasoning through legal arguments is a science that provides principles that must be followed in order to be able to think validly according to applicable rules. This is because, scientific reasoning requires proof of truth in an integrated way. Orientation in conducting research indicates that there is a close relationship between the philosophical views of a researcher with the methods chosen and used in conducting research. This study was conducted to determine the urgency of the need for legal reasoning for candidates and experts from law graduates to be applied in the future. So from here it is hoped that a good and correct flow of scientific reasoning can be born.
\end{abstract}

Keywords: Legal Argument; Science; Reasoning

\begin{abstract}
Abstrak
Penalaran memiliki peran yang sangat penting dalam pengembangan pengetahuan serta pengkajian-pengkajian pengetahuan tertentu. Sebagai sebuah ilmu pengetahuan ia menjadi dasar yang menentukan pemikiran agar lurus, tepat dan sehat. Sebab fungsi penalaran adalah menyelidiki, merumuskan serta menerapkan hukum-hukum yang ditepati. Penalaran melalui argumentasi hukum merupakan ilmu yang memberikan prinsip-prinsip yang harus diikuti agar dapat berpikir valid menurut aturan yang berlaku. Ini dikarenakan, penalaran ilmiah menghendaki pembuktian kebenaran secara terpadu. Orientasi didalam melakukan penelitian mengindikasikan adanya suatu kaitan yang erat antara pandangan filsafati seorang peneliti dengan metode yang dipilih dan digunakan dalam melakukan penelitian. Tulisan ini ditujukan untuk mengetahui urgensi diperlukannya penalaran hukum bagi para calon maupun ahli dari lulusan hukum untuk diterapkan di masa depan, sehingga dari sini diharapkan dapat melahirkan alur penalaran ilmiah yang baik dan benar.
\end{abstract}

Kata Kunci: Argumentasi Hukum; Ilmu Pengetahuan; Penalaran

\section{A. Pendahuluan}

Dewasa ini, dalam wacana publik, khazanah intelektual, dan praktik hukum di tanah air, peran logika dan penalaran hukum dalam studi hukum semakin diperhitungkan. Banyak pemikir menyatakan bahwa untuk menjadi lawyer, hakim, jaksa, atau praktisi hukum yang handal, pemahaman terhadap logika, penalaran hukum, dan argumentasi hukum merupakan syarat 
mutlak yang tak bisa ditawar-tawar. ${ }^{1} \mathrm{Hal}$ tersebut mencerminkan bahwa pentingnya para lulusan bidang hukum untuk dapat memahami dan mengetahui secara komprehensif apa yang dimaknai sebagai argumentasi hukum.

Hanson dalam buku Legal Method, Skills, and Reasoning, ${ }^{2}$ menyatakan bahwa studi hukum secara kritis dari sudut pandang logika, penalaran hukum, dan argumentasi hukum dibutuhkan karena pemahaman hukum dari perspektif semacam ini berusaha menemukan, mengungkap, menguji akurasi, dan menjustifikasi asumsi-asumsi atau makna-makna yang tersembunyi dalam peraturan atau ketentuan hukum yang ada berdasarkan kemampuan rasio (akal budi) manusia. Kemampuan semacam ini tidak hanya dibutuhkan bagi mereka yang berkecimpung dalam bidang hukum melainkan juga dalam seluruh bidang ilmu dan pengetahuan di luar hukum.

Harus diakui bahwa konsep, pemahaman dan studi tentang logika, penalaran, dan argumentasi hukum meskipun sering didiskusikan dalam hukum tetapi jarangdijelaskan, dielaborasi, dan ditelaah secara memadai. Mahasiswa hukum sering dituntut untuk berpikir seperti seorang ahli hukum, "to think like a lawyer". Mereka diharapkan kelak mampu menganalisis kasus hukum melalui medium penalaran hukum dalam kasus-kasus hukum entah dalam wilayah publik, akademik, atau pengadilan. Di samping itu mahasiswa pun diharapkan mampu memahami secara kritis, rasional, dan teori argumentasi, rumusan undang-undang, opini, maupun pendapat hukum.

Kurangnya diskusi dan pembahasan mengenai argumentasi hukum tentu dapat berpengaruh pada pemikiran dari mahasiswa atau lulusan hukum di kemudian hari. Karena dengan berpikir secara kritis, logis, dan mendalam dibutuhkan pemahaman mengenai argumentasi hukum itu sendiri. Tidak dapat disangkal bahwa logika dan penalaran hukum (legal reasoning) sering ditolak. Sebagian pendapat menyatakan bahwa hukum berurusan dengan data, fakta, atau pengalaman praktis dan bukan pemikiran abstrak, rasional atau logis. Penalaran hukum lalu dianggap tidak perlu diajarkan kepada mereka yang mempelajari hukum karena tidak "membumi". Hukum harus dipelajari melalui pengalaman konkrit saja. ${ }^{3}$ Hal tersebut tentu tidak dapat serta merta dianggap benar. Hukum adalah aturan mengenai bagaimana seseorang seharusnya bertindak, sehingga hal tersebut mencerminkan bahwa hukum merupakan sebuah rumusan yang abstrak tentang sesuatu yang dalam hal ini adalah tindakan dan bukanlah tindakan itu sendiri.

Berdasarkan paparan singkat di atas, maka sebenarnya terdapat urgensi perlunya memasifkan penalaran dalam argumentasi hukum yang dibutuhkan oleh generasi yang

\footnotetext{
1 Urbanus Ura Weruin, "Logika, Penalaran, dan Argumentasi Hukum”,Jurnal Konstitusi, Volume 14, Nomor 2, Juni 2017, hlm. 375.

${ }^{2}$ Sharon Hanson (ed.), Legal Method, Skills, and Reasoning, Milton Park-Abingdon-Oxon: RoutledgeCavendish, 2010, hlm. 5-8.

${ }^{3}$ Urbanus Ura Weruin, Op. Cit.
} 
berkecimpung di dunia hukum. Hal tersebut bukanlah tanpa sebab, tentu saja terdapat hal-hal yang dibutuhkan oleh calon-calon bahkan ahli hukum untuk dapat berpikir dengan nalar untuk dapat mahir dalam memutus permasalahan yang ada dan hadir untuk diselesaikan melalui adanya hukum itu sendiri. Sehingga dalam artikel ilmiah kali ini, akan dibahas mengenai urgensi penalaran dalam argumentasi hukum guna mengembangkan pemikiran hukum yang komprehensif untuk mengemukakan seberapa penting adanya penalaran hukum untuk dipelajari dan dikuasai oleh para calon maupun ahli hukum. Pentingnya pembahasan mengenai hal ini adalah untuk memahami apa yang dimaksud dengan penalaran dan kaitannya dengan ilmu hukum, serta untuk mengetahui urgensi diperlukannya penalaran hukum bagi para pemikir hukum untuk diterapkan di masa depan.

Dalam tulisan ini, dua permasalahan yang dibahas oleh penulis adalah: Bagaimanakah yang disebut dengan penalaran itu dan apa kaitannya dengan argumentasi hukum? Selain itu dibahas mengenai bagaimanakah urgensi penalaran dalam argumentasi hukum sebagai pendorong meningkatnya pemahaman hukum guna pengembangan pemikiran yang lebih komprehensif?

\section{B. Pembahasan}

\section{Penalaran dan Kaitannya dengan Ilmu Hukum}

Manusia fitrahnya berkemampuan menalar, yaitu mampu untuk berpikir secara logis dan analistis, dan diakhiri dengan kesimpulan. ${ }^{4}$ Kemampuan ini berkembang seiring dengan berkembangnya bahasa komunikasi ilmiah sehingga hal-hal yang sifatnya abstrak juga mampu dikembangkan, hingga akhirnya sampai pada tingkatan yang dapat dipahami dengan mudah.

Ketidakpuasan atas keilmuan yang dibangun diatas pemikiran awam terus mendorong berbagai disiplin keilmuan, salah satunya adalah filsafat. Filsafat mengurai kembali semua asumsi tersebut guna mendapatkan sebuah pengetahuan yang hakiki. ${ }^{5}$ Setiap kepala memiliki pemikirannya masing-masing, begitu pula dengan para ilmuan, setiap individu merujuk pada filsatat yang sama, yaitu penggunaan metode IImiah dalam menyelesaikan sebuah problematika keilmuan yang mereka hadapi. ${ }^{6}$ Karena penggunaan metode ilmiah dalam sebuah wacana keilmuan dapat meringankan ilmuan dan pengikutnya dalam melacak kebenaran wacana mereka tersebut. Sehigga akhirnya lahirlah sebuah asumsi bahwa dalam pengetahuan ilmiah semua kebenaran dapat dipertanggung jawabkan, meskipun hanya atas nama logika. Karena pada hakekatnya setiap kebenaran ilmiah selalu diperkuat dengan adanya bukti-bukti

\footnotetext{
${ }^{4}$ Noor Ms Bakry, Logika Praktis Dasar Filsafat dan Sarana Ilmu, Yogyakarta: Liberty, 2001, hlm. 55.

${ }^{5}$ Fritjop Capra, Titik Balik Peradaban: Sains Masyarakat dan Kebangkitan Kebudayaan, terj. M. Thoyibi, Yogyakarta: Yayasan Bentang Budaya, 1998.

${ }^{6}$ Noeng Muhadjir, Metodologi Penelitian Kualitatif,Yogyakarta: Rake Sarasin, 2006, ed. 3, hlm. 13-15.
} 
empiris maupun indrawi yang mengikutinya. ${ }^{7}$ Sehingga dalam berpikir secara ilmiah, seharusnya setiap orang dapat berpikir dengan ditopang pula oleh logika.

IImu sering diartikan sebagai suatu alat untuk mengetahui segala hal yang belum diketahui, baik ia bersifar riil, ataupun abstrak, dengan keyakinan yang berdasar, entah ia sesuai dengan kenyataan ataupun tidak. ${ }^{8}$ Adapun logika sering diartikan sebagai suatu cara bernalar secara sistematis, atau tepatnya cara untuk mencari jalan, guna tercapainya ilmu yang benar.Karena kedua hal tersebut tidaklah mungkin dapat dispisahkan, karena keduanya saling melengkapi satu sama lainnya. sehingga dapat disimpulakan bahwa logika merupakan jalan untuk mencapai pengetahuan yang benar, dan ilmu yang benar membutuhkan tentu saja membutuhkan logika.

Pada umumnya, logika dianggap sebagai instrumen untuk membuat intelligen tindakan yang terlibat rekonstruksi situasi problematik. Tindakan tersebut akan melahirkan sebuah proses, yang simbolisasi dan proposional.Proposisi-proposisi ini pada umumnya merupakan alat-alat logis, yang merupakan serangkaian keputusan yang diambil. Dan karena instrumen tersebut adalah berupa ide, maka kebenaran ataupun nilainya ditentukan seperti menentukan kebaikan sebuah alat, dengan cara menggunakannya dalam praktek, ataupun dalam memecahkan masalah. ${ }^{9}$ Sehingga dapat diartikan bahwa kebenaran alat tersebut akan ditentukan dengan bagaimana keadaan, dan hasil darinya ketika ia digunakan dalam sebuah praktek dalam memecahkan permasalahan.

Rumusan aturan hukum tidak lain dari usaha mengeksplisitasi gagasan atau prinsip hidup yang abstrak dalam norma kehidupan nyata. Tidak berlebihan untuk menyatakan bahwa hukum sebagian bersumber dari prinsip hidup ideal. Tak dapat disangkal bahwa logika murni (pure logic), logika formal, atau logika simbolik, sangat bolehjadi cukup "abstrak-ideal" dan mungkin memiliki peran terbatas dalam merumuskan atau menganalisis putusan-putusan pengadilan, mencermati aturan-aturan hukum, memetakan opini dan pendapat hukum. Tetapi logika dasar seperti penyimpulan langsung, deduksi dan induksi, kesesatan berpikir merupakan alat berpikir yang dapat digunakan untuk memperoleh kebenaran hukum yang semakin bisa dipertanggungjawabkan secara rasional dan ilmiah. ${ }^{10}$

Berasumsi bahwa logika tidak selalu merupakan basis primer bagi putusan hukum (legal decision) dan logika seharusnya tidak boleh berperan sebagai sarana justifikasi (justification) kebenaran hukum, bukanlah sebuah argumen yang memadai. Karena proses berargumentasi itu tidak lain dari proses menjustifikasi. Dalam konteks itulah studi dan penelitian literer terhadap logika, penalaran, dan argumentasi hukum tidak hanya semakin diperlukan melainkan juga

\footnotetext{
${ }^{7}$ Budi F. Hardiman, Filsafat Modern, Jakarta: Gramedia, 2004, hlm. 215

${ }^{8}$ Zainal Abidin Bagir, Integrasi IImu dan Agama: Interpretasi dan Aksi, Bandung: Mizan Pustaka, 2005, hlm. 113.

${ }^{9}$ Haninah, Agama Pragmatis, Yogyakarta: Indonesia Tera, 2001, hlm. 51-52.

${ }^{10}$ Urbanus Ura Weruin, Op.Cit.
} 
selalu relevan. Karena studi tentang logika, penalaran, dan argumentasi hukum tidak lain dari upaya menjelaskan kriteria-kriteria logis mana yang dapat digunakan untuk menentukan suatu aturan, argumen, pendapat, atau putusan hukum baik atau buruk, benar atau salah dan dapat diterima atau ditolak.

Muncul logika sebagai suatu cara berfikir, tidak bisa begitu saja terlepas dari pengaruh pemikiran silogisme Aristoteles. ${ }^{11}$ Meskipun hasil berfikir tidak semuanya membuahkan tindakan, adakalanya saat hal itu hanya akan menjadi hanya sebagai buah pikiran belaka. Ini juga tidak menutup kemungkinan untuk berarkhir dalam sebuah tindakan konkret. Logika sendiri tidak semata-mata lahir sebagai sebuah cara berfikir dalam memandang hidup yang tersusun rapi, namun sejatinya ia mengalami proses yang dimulai dari logika sebagai metode berfikir. la kemudian bergulir dan berkembang menjadi sebuah landasan pengembangan ilmu dan akhirnya menjelma sebagai suatu cara pandang terhadap dunia (worldview).

\section{Urgensi Penalaran dalam Argumentasi Hukum sebagai Pendorong Meningkatnya Pemahaman Hukum}

Logika menurut Aristoteles tidak lepas dari istilah silogistik. la merupakan sebuah penjelasan yang dalam prosesnya mengandung unsur "abstraksi/premis mayor" dan "difinisi/premis minor" keduanya diperlukan untuk membangun sebuah konsep yang benar sebelum melangkah menjadiproposisi. ${ }^{12}$ Proposisi tersebut lah yang akan bermuara kepada sebuah kesimpulan. Penalaran dalam fungsinya sebagai kegiatan berfikir tentunya memiliki karakteristik atau ciri-ciri tertentu.

Pertama, adanya pola berfikir yang secara luas (logis), hal inilah yang sering disebut sebagai logika. Selanjutnya dapat dikatakan bahwa setiap usaha penalaran mempunyai logikanya tersendiri karena ia merupakan sebuah proses berfikir. ${ }^{13}$ Sehingga Berfikir secara logis dapat dimaknai sebagai suatu pola, dan ketentuan tertentu yang digunakan dalam proses berfikir. Maka dari itu sebuah kerangka logika dalam satu hal tertentu sangat mungkin dianggap tidak logis jika ditinjau dari kerangka lainnya. Hal inilah yang menimbulkan adanya ketidakkonsistenan dalam menggunakan pola pikir, yang akhirnya melahirkan beberapa motode pendekatan yang bermacam-macam.

Kedua, penalaran harus bersifat analistik, dengan maksud ia merupakan pencerminan dari suatu proses berfikir yang bersandar pada suatu analisa dan kerangka berfikir tertentu, dengan logika sebagai pijakannya. Secara sederhananya poin kedua ini merupakan sebuah proses menganalisa dengan logika ilmiah sebagai pijakannya. Dalam hal ini, analisa

\footnotetext{
${ }^{11}$ Muhammad Muslih, Filsafat IImu:Kajian atas Asumsi Dasar Paradigma dan Kerangka Teori IImu Pengetahuan, Yogyakarta: Belukar, 2008, hlm. 207.

${ }^{12}$ Mundiri, Logika, Jakarta: PT Raja Grafindo Persada, 2000, cet.4, hlm. 45-46.

${ }^{13}$ Mohammad Muslih, "Problem Keilmuan Kontemporer dan Pengaruhnya Terhadap Dunia Pendidikan" Tsaqafah jurnal Peradaban Islam, vol.8, No. 1, April 2012, hlm. 30.
} 
merupakan suatu kegiatan berfikir dengan langkah-langkah yang tertentu. Sehingga kegiatan berfikir tidak semuanya berlandaskan pada penalaran. Maka dari itu berfikir dapat dibedakan mana yang menggunakan dasar logika dan analisa, serta mana yang tanpa menggunakan penalaran seperti menggunakan perasaan, intuisi, ataupun hal lainnya. Karena hal-hal tersebut bersifat non-analistik, yang tidak mendasarkan diri pada suatu pola berfikir tertentu. ${ }^{14}$

Pengetahuan selalu berkembang dengan ukuran-ukuran yang konkrit, model, dan metodologi, serta observasi. Hingga dalam perkembangannya model dan cara berfikir yang dianggap kuno telah memperoleh gugatan. Hal ini dikarenakan, tidak semua ilmu pengetahuan dapat didekati dengan cara yang sama. Sehingga ditemukannya metodeberfikir ilmiah, secara langsung telah membawa terjadinya perkembangan dalam ilmu pengetahuan. Manusia bukan saja hidup dalam kondisi modernisasi yang serba mudah dan praktis. Lebih dari itu, kini manusia mampu menggapai sesuatu yang sebelumnya seolah tidak mungkin. Manusia tidak lagi diam, atas apa yang terjadi, sebagai akibat dari perkembangan logika manusia.

Satu hal dalam logika penalaran, yang menjadi pertimbangan adalah pernyataanpernyataan yang ada sebelumnya. Masing-masing hanya dapat bernilai salah atau benar namun tidak keduanya. Hal inilah yang sebelumnya disebut sebagai proposisi. Proposisi yang telah dihimpun ini nantinya akan dapat dievaluasi dengan beberapa cara, seperti: deduksi, dan induksi. Maka dari itu, poin pembahasan yang relevan dengan topik wacana kali ini, adalah metode induksi dan deduksi. Yang secara singkat jika metode induksi diartikan sebagai salah satu cara untuk menarik kesimpulan yang umum digunakan oleh para ilmuwan. Maka metode deduksi adalah kebalikan dari metode induksi, karena ia menarik kesimpulan kepada yang lebih khusus, dan terperinci.

Adapun tujuan dari penggunaan kedua metode ilmiah ini tiada lain adalah agar ilmu berkembang dan tetap eksis dan mampu menjawab berbagai tantangan yang dihadapi. Serta mendapakan sebuah kebenaran dan kesesuaian antara kajian ilmiah, dengan tanpa terbatas ruang, waktu, tempat dan kondisi tertentu. ${ }^{15}$

Terlepas dari pro kontra tentang logika, penalaran, dan argumentasi hukum, penalaran hukum mesti diajarkan kepada mahasiswa hukum. Peter Nash Swisher (1981) menegaskan bahwa mahasiswa hukum perlu diajarkan prinsip-prinsip logika dasar dan penalaran hukum. Ibarat seorang perenang yang perlu mempelajari teknik dan cara berenang agar tetap survive, demikian juga mahasiswa hukum perlu dibekali dengan pemahaman dan keterampilan penalaran hukum agar bisa survive. ${ }^{16}$ Keterampilan dasar dan elementer dalam penalaran hukum lebih baik diberikan kepada mahasiswa hukum dari pada tidak memilikinya sama sekali.

\footnotetext{
14 Ibid.

${ }_{15}^{15}$ Milton D. Hunnex, Peta filsafat: Pendekatan Kronoligis dan Tematik,Jakarta: Teraju, 2004, hlm. 1-9.

${ }^{16}$ Urbanus Ura Weruin, Op. Cit., hlm. 379
} 
Dengan logika dan penalaran hukum, mahasiswa dan para praktisi hukum mampu memahami hukum secara kritis dan rasional serta menunjukkan dasar-dasar dari klaim suatu hukum.

Filsafat sendiri tidak dapat didefinisikan secara pasti, karena ia berkaitan dengan masingmasing filsuf yang berkaitan dengannya. Seperti Plato, yang menyatakan filsafat sebagai ilmu yang berusaha meraih sebuah kebenaran yang murni. Adapun menurut Aristoteles, ia adalah suatu ilmu pengetahuan yang berusaha mencari prinsip-prinsip dan penyebab dari adanya suatu realitas. ${ }^{17}$ Namun secara singkat kita dapat mendefinisikannya sebagai suatu ilmu pengetahuan yang berusaha memahami hakekat alam, dan realitas, serta membawa manusia untuk menelusuri batas-batas kemanusiaan, dan mengimani batas-batas ketuhanan, yang artinya ia sangat berkaitan dengan rasio dalam menalar dan iman dalam meyakini. ${ }^{18}$

Dalam perkembangannya, filsafat sering dikatakan sebagai kakak kandung dari logika, maka dari itu ia harus lebih "pintar" dari logika itu sendiri. Hal ini dikarenakan bahwa inti dari filsafat adalah membentuk sebuah pola pikir, bukan sekedar mengisi kepada dengan faktafakta. Sehingga kelebihan filsafat itu sendiri dapat dikatakan mampu melengkapi manusia dalam banyak bidang non akademis, bahkan ia juga diplot mampu membawa perubahan kemandirian intelektual, dan dogmatis. ${ }^{19}$ Maka dari itu, berfilsafat berarti menyusun dan mempertanyakan keyakinan-keyakinan seseorang dengan menggunakan argumentasi rasional. ${ }^{20}$

\section{Simpulan}

Penalaran atau metode berfikir ilmiah menghendaki pembuktian kebenaran secara terpadu antara kebenaran rasional dan kebenaran faktual, serta menggabungkan penalaran deduktif dan induktif dengan menggunakan asumsi dasar atau hipotesa sebagai jembatan penghubungnya. Induksi dan deduksi sebagai penalaran atau metode ilmiah bukan tanpa kekurangan, karena itu tugas kita adalah mencoba untuk mengidentifikasi apa kelebihan dan kekurangan metode ilmiah ini. Tujuannya adalah untuk mendapatkan metode penalaran ilmiah yang menghendaki pembuktian kebenaran secara terpadu antara kebenaran rasional dan kebenaran faktual, menggabungkan penalaran deduktif dan induktif dengan menggunakan hipotesis sebagai jembatan penghubungnya. Sehingga dari sini diharapkan dapat melahirkan alur penalaran ilmiah yang baik dan benar.

\footnotetext{
17 Jan Hendrik Rapar, Pustaka Filsafat Pengantar Filsafat, Yogyakarta: Kanisius, hlm. 14-15.

${ }^{18}$ Imron Mustofa, "Jendela Logika dalam Berfikir: Deduksi dan Induksi sebagai Dasar Penalaran IImiah" EL-BANAT: Jurnal Pemikiran dan Pendidikan Islam, Volume 6, Nomor 2, Juli-Desember 2016, hlm. 130

${ }^{19}$ Mark B. Woodhouse, Berfilsafat: Sebuah Langkah Awal,Yogyakarta: Kanisius, 2000, hlm. 49.

${ }^{20}$ M. Sastrapratedja, Etika dan Hukum: Relevansi Teori Hukum Kodrat Th. Aquinas, Yogyakarta: Kanisius, 2002, hlm. 13. Ibid.
} 


\section{DAFTAR PUSTAKA}

\section{BUKU}

Weruin, Urbanus Ura. "Logika, Penalaran, dan Argumentasi Hukum". Jurnal Konstitusi, Volume 14. Nomor 2. Juni 2017.

Hanson, Sharon. Legal Method, Skills, and Reasoning, Milton Park-Abingdon-Oxon: RoutledgeCavendish. 2010.

Bakry, Noor Ms. Logika Praktis Dasar Filsafat dan Sarana Ilmu. Yogyakarta: Liberty. 2001.

Capra, Fritjop. Titik Balik Peradaban: Sains Masyarakat dan Kebangkitan Kebudayaan, terj. M. Thoyibi, Yogyakarta: Yayasan Bentang Budaya. 1998.

Sastrapratedja, M. Etika dan Hukum: Relevansi Teori Hukum Kodrat Th. Aquinas. Yogyakarta: Kanisius. 2002.

Woodhouse, Mark B. Berfilsafat: Sebuah Langkah Awal, Yogyakarta: Kanisius. 2000.

Muhadjir, Noeng. Metodologi Penelitian Kualitatif.Yogyakarta: Rake Sarasin. 2006. ed. 3.

Haninah. Agama Pragmatis. Yogyakarta: Indonesia Tera. 2001.

Hardiman, Budi F. Filsafat Modern.Jakarta: Gramedia. 2004.

Hunnex, Milton D. Peta filsafat: Pendekatan Kronoligis dan Tematik.Jakarta: Teraju. 2004.

Rapar, Jan Hendrik. Pustaka Filsafat Pengantar Filsafat. Yogyakarta: Kanisius.

Muslih,Muhammad.Filsafat IImu: Kajian atas Asumsi Dasar Paradigma dan Kerangka Teori IImu Pengetahuan.Yogyakarta: Belukar. 2008.

Mundiri. Logika. Jakarta: PT Raja Grafindo Persada. 2000. cet. 4.

Bagir, Zainal Abidin.Integrasi Ilmu dan Agama: Interpretasi dan Aksi. Bandung: Mizan Pustaka. 2005.

\section{JURNAL}

Muslih, Mohammad. "Problem Keilmuan Kontemporer dan Pengaruhnya Terhadap Dunia Pendidikan" Tsaqafah jurnal Peradaban Islam. vol. 8. No. 1. April 2012.

Mustofa, Imron. "Jendela Logika dalam Berfikir: Deduksi dan Induksi sebagai Dasar Penalaran IImiah" EL-BANAT: Jurnal Pemikiran dan Pendidikan Islam. Volume 6. Nomor 2. JuliDesember 2016. 